\title{
PENGEMBANGAN PERANGKAT PEMBELAJARAN FISIKA BERBASIS MASALAH UNTUK MENINGKATKAN KEMAMPUAN BERPIKIR KRITIS PESERTA DIDIK
}

\author{
* Ardiansah Hasin* \\ Pasca Sarjanan Universitas \\ Negeri Makassar \\ ardiansah.hasin@gmail.com
}

Sidin Ali

Universitas Negeri Makassar msidin.ali@unm.ac.id

Kaharuddin Arafah

Universitas Negeri Makassar kaharuddin.arafah@unm.ac.id

*koresponden author
Abstrak - Penelitian ini bertujuan untuk : memeroleh informasi tentang profil perangkat pembelajaran berbasis masalah, mengetahui apakah kemampuan berpikir kritis yang diperoleh peserta didik yang diajar melalui model pembelajaran berbasis masalah lebih baik dibandingkan dengan peserta didik yang diajar tanpa melalui model pembelajaran berbasis dan mengetahui respon peserta didik terhadap perangkat pembelajaran fisika berbasis masalah untuk meningkatkan kemampuan berpikir kritis peserta didik. Desain penelitian yang digunakan adalah Posttest Only Control Group Design. Pengumpulan data dilakukan melalui observasi dan tes kemampuan berpikir kritis kemudian data dianalisis dengan menggunakan analisis deskriptif-inferensial. Kemampuan berpikir kritis dapat tercapai secara optimal melalui pembelajaran dengan menggunakan pembelajaran berbasis masalah. Hasil analisis deskriptif menunjukkan bahwa nilai rata-rata skor tes kemampuan berpikir kritis peserta didik yang diajar melalui model pembelajaran berbasis masalah sebesar 56,63 dan standar deviasinya 7,17. Sedangkan nilai rata-rata skor tes kemampuan berpikir kritis peserta didik Kelas XI IPA 2 MAN 2 Model makassar yang diajar tanpa menggunakan model pembelajaran berbasis masalah sebesar 39,23 dan standar deviasinya 8,32. Hasil analisis inferensial menunjukkan bahwa Kemampuan berpikir kritis peserta didik yang diajar melalui model pembelajaran berbasis masalah lebih baik dibandingkan peserta didik yang tidak diajar dengan menggunakan model pembelajaran berbasis masalah pada taraf nyata $\alpha=0,05$

Kata Kunci : Perangkat pembelajaran berbasis masalah, kemampuan berpikir kritis

Abstract - This study aims are to obtain information about the profile of problem-based learning, the know that critical thinking skills of students are taught acquired through problem-based learning model is better than students who are taught without going through the model-based learning and, to study the response of the physics problem-based learning devices to improve critical thinking skills of students. The data was collected through observation and critical thinking skills test to measure critical thinking skills of students and then the data were analysed using descriptive-inferential analysis. Hypothesis of this research is critical thinking skills students who are taught through problem-based learning model are better than learners who are not taught to use problem-based learning model. Critical thinking skills can be improved optimally through learning by using problem-based learning. Results of descriptive analysis showed that the average test scores of critical thinking skills of students from the second years of Exact 2 class are taught through problem-based learning model are 56.63 and their standard deviation 7.17. While the average value of critical thinking skills test scores of students from the second years of Exact 2 class of in MAN 2 Model Makassar who are taught without the use of problem-based learning model are 39.23 and their standard deviation 8.32. Inferential analysis results showed that the critical thinking skills of students who are taught through problem-based learning model is better than learners who are not taught to use problem-based learning model on a real level $\alpha=0.05$.

Keywords : Problem-Based Learning Devices, Critical Thinking Ability 


\section{A. PENDAhULUAN}

Perkembangan ilmu pengetahuan dan teknologi menuntut perkembangan dunia pendidikan. Melalui pendidikan seseorang akan mendapatkan berbagai macam ilmu pengetahuan dan teknologi. Tanpa pendidikan, seseorang tidak akan pernah tahu tentang perkembangan dunia luar bahkan tidak bisa bersaing di dunia luar.

Ilmu pengetahuan alam (IPA) berkaitan dengan cara mencari tahu tentang alam secara sistematis, sehingga IPA bukan hanya sekumpulan penguasaan pengetahuan yang berupa fakta-fakta, konsep-konsep, atau prinsip-prinsip saja, tetapi juga merupakan suatu proses penemuan. Ilmu pengetahuan alam dimaksud untuk mengenal, menyikapi, dan mengapresiasi ilmu pengetahuan, serta menanamkan kebiasan berpikir kritis dan berprilaku ilmiah yang kritis, kreatif, dan mandiri. (peraturan menteri pendidikan nasional Republik Indonesia nomor 22, 2006: 45).

Berdasarkan hasil observasi yang dilakukan oleh peneliti di MAN 2 Model Makassar menunjukkan bahwa proses pembelajaran fisika masih berpusat pada guru dan lebih menekankan pada proses pemindahan pengetahuan dari guru kepada peserta didik sehingga tidak menempatkan peserta didik sebagai pengonstruksi pengetahuan. Guru menggunakan cara yang kurang sesuai dengan kondisi peserta didik dan biasanya guru hanya mengajar materi yang diajarkan tanpa mengaitkan penerapan dalam kehidupan sehari-hari sehingga sulit untuk memahami/menguasai konsep materi pelajaran. Guru memegang peran aktif dalam proses pembelajaran, sedangkan peserta didik cenderung diam dan secara pasif menerima materi pelajaran, peserta didik juga kurang berani mengungkapkan gagasannya.

Hasil belajar peserta didik MAN 2 Model Makassar masih rendah. Hal ini ditunjukkan dengan data dari ujian tengah semester (MID) pada semester ganjil kelas XI IPA tahun pelajaran 2011-2012 pada MAN 2 Model Makassar sebanyak 5 kelas atau 175 peserta didik dengan Kriteria Ketuntasan Minimal (KKM) 70 hanya 97 peserta didik atau 55,42 \% peserta didik yang tuntas. Hal ini menunjukkan bahwa tingkat ketuntasan belajar belum memenuhi kriteria ketuntasan yang dipersyaratkan secara nasional yaitu $85 \%$.

Hasil observasi peneliti : 1) peserta didik tidak banyak yang siap atau menyiapkan diri sebelum pembelajaran dimulai walaupun materi pelajaran yang akan diajarkan pada pertemuan berikutnya sudah diketahui, 2) aktivitas peserta didik dalam proses pembelajaran masih rendah, dan 3) peserta didik belum mampu memecahkan suatu permasalahan dengan baik, yang mencerminkan kemampuan berpikir secara kritis masih rendah.

Model pembelajaran berbasis masalah dapat menjadi salah satu solusi untuk mendorong peserta didik berpikir kritis dan bekerja dibandingkan menghafal dan bercerita sehingga proses pembelajaran bukan hanya milik guru semata, tetapi peserta didik pun ikut aktif dan merasa bahwa keberadaannya merupakan tujuan dari proses pembelajaran (student centre).

Berikut ini beberapa kelebihan model pembelajaran berbasis masalah yang antara lain: (1) mendorong kerjasama dalam menyelesaikan tugas; (2) mendorong peserta didik melakukan 
pengamatan dialog dengan orang lain; (3) melibatkan peserta didik dalam penyelidikan; (4) membantu peserta didik menjadi pebelajar yang mandiri.

Dalam model pembelajaran berbasis masalah, perangkat pembelajaran yang digunakan adalah Rencana Pelaksanaan Pembelajaran (RPP), Buku Peserta Didik (BPD), Lembar Kerja Peserta didik (LKPD), dan Tes Kemampuan Berpikir Kritis (TKBK). Perangkat pembelajaran yang berhasil dikembangkan selanjutnya diujicobakan pada peserta didik MAN 2 Model Makasaar untuk mengetahui kemampuan berpikir kritis peserta didik. Uji coba dimaksudkan untuk mengetahui apakah perangkat pembelajaran yang dikembangkan efektif dalam meningkatkan kemampuan berpikir kritis peserta didik. Bertolak dari uraian di atas, peneliti akan melakukan penelitian pengembangan perangkat pembelajaran dengan judul "Pengembangan Perangkat Pembelajaran Fisika Berbasis Masalah untuk Meningkatkan Kemampuan Berpikir Kritis Peserta Didik”.

\section{B. METODE}

Jenis penelitian ini merupakan penelitian pengembangan (research and development). Untuk mengetahui kemampuan berpikir kritis fisika dapat tercapai secara optimal digunakan model postest only control group desain. Secara sederhana diagram desain ini sebagai berikut.

$$
\begin{aligned}
& \mathrm{R} \quad \mathrm{O}_{1} \\
& \mathrm{R}-\mathrm{O}_{2}
\end{aligned}
$$

(Sugiono, 2010: 323)

Subjek populasi dalam penelitian ini adalah peserta didik kelas XI IPA MAN 2 Model Makassar yang terdiri dari 5 kelas yang berjumlah 175 peserta didik pada semester genap tahun pelajaran 2011-2012. Untuk menganalisis data pada pengembangan perangkat pembelajaran ini akan digunakan teknik analisis statistik deskriptif dan teknik analisis statistik inferensial. Data yang dianalisis adalah sebagai berikut.

\section{Analisis Data Hasil Validasi Perangkat Pembelajaran dan Lembar Instrumen Penelitian.}

Teknik Hoyt ini menyelesaikan uji keandalan melalui analisis variansi amatan ulangan dengan rumus sebagai berikut.

$$
r_{i j}=\frac{R K_{\text {subjek }}-R K_{\text {interkasi }}}{R K_{\text {subjek }}}
$$

(Sutrisno, 1991: 50)

Perangkat pembelajaran dan instrumen dikatakan baik jika mempunyai koefisien reliabilitas $\geq 0,70$ atau $\geq 70 \%$.

\section{Analisis Keterlaksanaan Perangkat Pembelajaran}

Mencari rata-rata tiap aspek pengamatan untuk $t$ kali pertemuan dengan rumus:

$$
\bar{A}_{l}=\frac{\sum_{m=1}^{t} A_{m l}}{t}
$$

(Nurdin, 2007: 143) 
keterangan:

$\overline{A_{l}}=$ rata-rata nilai aspek ke-i

$\mathrm{A}_{\mathrm{mi}}=$ rata-rata aspek ke-pertemuan ke-m

$\mathrm{t}=$ banyaknya pertemuan

Kategori keterlaksanaan setiap aspek atau keseluruhan aspek keterlaksanaan perangkat yang dikutip dari Nurdin (2007: 144) adalah :

$$
\begin{array}{ll}
1,5 \leq \mathrm{M} \leq 2,0 & \text { terlaksana seluruhnya } \\
0,5 \leq \mathrm{M}<1,5 & \text { terlaksana sebagian } \\
0,0 \leq \mathrm{M}<0,5 & \text { tidak terlaksana }
\end{array}
$$

\section{Analisis Pengamatan Pengelolaan Pembelajaran Fisika Berbasis Masalah}

Interval penentuan kategori kemampuan guru mengelola pembelajaran dengan model pembelajaran berbasis masalah sebagai berikut (Darwis, 2007: 45).

$$
\begin{array}{ll}
3,5 \leq \overline{K G} \leq 4 & \text { sangat tinggi (ST) } \\
2,5 \leq \overline{K G}<3,5 & \text { tinggi (T) } \\
1,5 \leq \overline{K G}<2,5 & \text { cukup tinggi/sedang (CT) } \\
\overline{K G}<1,5 & \text { tidak tinggi/rendah (TT) }
\end{array}
$$

\section{Data Respon Peserta Didik terhadap Perangkat Pembelajaran}

Analisis untuk menghitung persentase banyaknya peserta didik yang memberikan respon pada setiap kategori yang ditanyakan dalam lembar angket menggunakan rumus sebagai berikut:

$$
P R S=\frac{\sum A}{\sum B} \times 100 \%
$$

Keterangan:

PRS $=$ persentase banyak peserta didik yang memberikan respon positif terhadap kategori yang ditanyakan.

$\sum A=$ banyaknya peserta didik yang memberikan respon positif terhadap setiap kategori yang ditanyakan dalam angket.

$\sum B=$ banyaknya peserta didik yang menjadi subjek uji coba.

Sedangkan kriteria penilaiannya adalah:

$$
\begin{array}{ll}
81 \% \leq \mathrm{x} \leq 100 \% & \text { sangat setuju(SS) } \\
61 \% \leq \mathrm{x} \leq 80 \% & \text { setuju (S) } \\
41 \% \leq \mathrm{x} \leq 60 \% & \text { cukup setuju (CS) } \\
21 \% \leq \mathrm{x} \leq 40 \% & \text { tidak setuju (TS) } \\
\mathrm{x}<20 \% & \text { sangat tidak setuju( STS) }
\end{array}
$$

\section{Data Respon Peserta Didik terhadap Proses Pembelajaran}

Menentukan kategori untuk respon positif peserta didik dengan cara mencocokkan hasil persentase dengan kriteria yang ditetapkan.

Sedangkan kriteria penilaiannya adalah:

$$
81 \% \leq \mathrm{x} \leq 100 \% \text { sangat setuju(SS) }
$$




$$
\begin{array}{ll}
61 \% \leq \mathrm{x} \leq 80 \% & \text { setuju (S) } \\
41 \% \leq \mathrm{x} \leq 60 \% & \text { cukup setuju (CS) } \\
21 \% \leq \mathrm{x} \leq 40 \% & \text { tidak setuju (TS) } \\
\mathrm{x}<20 \% & \text { sangat tidak setuju( STS) }
\end{array}
$$

\section{Tes Kemampuan Berpikir Kritis}

Mencari rentang skor dengan cara membagi skor maksimun dengan skala yang digunakan yakni menggunakan skala lima.

$$
\text { Rentang skor }=\frac{\text { skor maksimum }}{\text { jumlah skala }}
$$

Tabel 1. Pedoman Pengategorian Tingkat Kemampuan Berpikir Kritis

\begin{tabular}{ccc}
\hline No. & Skor Interval & Kategori \\
\hline 1. & $65-80$ & Sangat tinggi \\
\hline 2. & $49-64$ & Tinggi \\
3. & $33-48$ & Sedang \\
4. & $17-32$ & Rendah \\
\hline 5. & $0-16$ & Sangat rendah \\
\hline
\end{tabular}

\section{Pengujian Normalitas}

Untuk mengetahui apakah data yang diperoleh berdistribusi normal, maka dalam penelitian ini digunakan uji Chi kuadrat $\left(\chi^{2}\right)$. Jika harga $\chi_{\text {hitung }}^{2} \leq \chi_{\text {tabel }}^{2}$ dengan $\mathrm{dk}=(\mathrm{k}-3)$ pada taraf nyata $\alpha=0,05$, maka data skor kemampuan berpikir kritis peserta didik berasal dari populasi yang berdistribusi normal.

\section{Pengujian Homogenitas}

Pengujian homogenitas dilakukan untuk menguji apakah varians kedua sampel homogen atau tidak. Kriteria pengujian: Bila harga $\mathrm{F}$ hitung lebih kecil atau sama dengan $\mathrm{F}$ tabel ( $F_{\text {hitung }} \leq \mathrm{F}_{\text {tabel }}$ ) maka Ho diterima dan Ha ditolak.

\section{Pengujian Hipotesis}

Pengujian hipotesis dimaksudkan untuk menjawab hipotesis yang telah diajukan dalam hipotesis penelitian, maka dari itu digunakan uji-t dengan uji satu pihak (uji pihak kanan) yang dirumuskan sebagai berikut. Tolak $\mathrm{H}_{0}$ jika $\mathrm{t}_{\text {hitung }}>\mathrm{t}_{\text {tabel }}$ dengan $\mathrm{dk}=\left(\mathrm{n}_{1}+\mathrm{n}_{2}-2\right)$ pada taraf signifikan $\alpha=0,05$ sedangkan untuk harga-harga lainnya $\mathrm{H}_{\mathrm{a}}$ diterima

\section{HASIL DAN PEMBAHASAN}

\section{A. Hasil Penelitian}

\section{Deskripsi Hasil Pengembangan (Develop)}

a. Hasil Validasi Perangkat Pembelajaran.

1) Rencana Pelaksanaan Pembelajaran (RPP). 
Tabel 2. Rangkuman Hasil Validasi RPP

\begin{tabular}{llc}
\hline No & \multicolumn{1}{c}{ Aspek penilaian } & $\overline{\boldsymbol{x}}$ \\
\hline 1 & Umum (komponen dan Identitas) & 3,88 \\
2 & Indikator & 3,50 \\
3 & Tujuan Pembelajaran & 4,00 \\
4 & Waktu & 3,50 \\
5 & Metode Pembelajaran & 3,75 \\
6 & Kegiatan Pembelajaran & 3,75 \\
7 & Bahasa dalam RPP & 3,63 \\
\hline & Rata-rata & 3,68 \\
\hline
\end{tabular}

2) Buku Peserta Didik (BPD)

Tabel 3. Rangkuman Hasil Validasi BPD

\begin{tabular}{llc}
\hline No & Aspek penilaian & $\overline{\boldsymbol{x}}$ \\
\hline 1 & kelayakan isi & 3,75 \\
2 & kelayakan bahasa & 3,63 \\
3 & kelayakan penyajian & 3,63 \\
\hline & Rata-rata total & 3,67 \\
\hline
\end{tabular}

3) Lembar Kerja Peserta Didik (LKPD)

Tabel 4. Rangkuman Hasil Validasi LKPD

\begin{tabular}{llc}
\hline No & Aspek penilaian & $\overline{\boldsymbol{x}}$ \\
\hline 1 & kelayakan isi & 3,75 \\
2 & kelayakan bahasa & 3,50 \\
3 & kelayakan penyajian & 3,75 \\
\hline & Rata-rata total & 3,67 \\
\hline
\end{tabular}

4) Tes Kemampuan Berpikir Kritis (TKBK)

Tabel 5. Rangkuman Hasil Validasi LKPD

\begin{tabular}{llc}
\hline No & \multicolumn{1}{c}{ Aspek penilaian } & $\overline{\boldsymbol{x}}$ \\
\hline 1 & Materi soal & 3,88 \\
2 & Konstruksi & 3,63 \\
3 & Bahasa & 3,88 \\
4 & Waktu & 3,25 \\
\hline & Rata-rata total & 3,66 \\
\hline
\end{tabular}

Hasil validasi perangkat pembelajaran ini dapat digambarkan pada grafik berikut. 


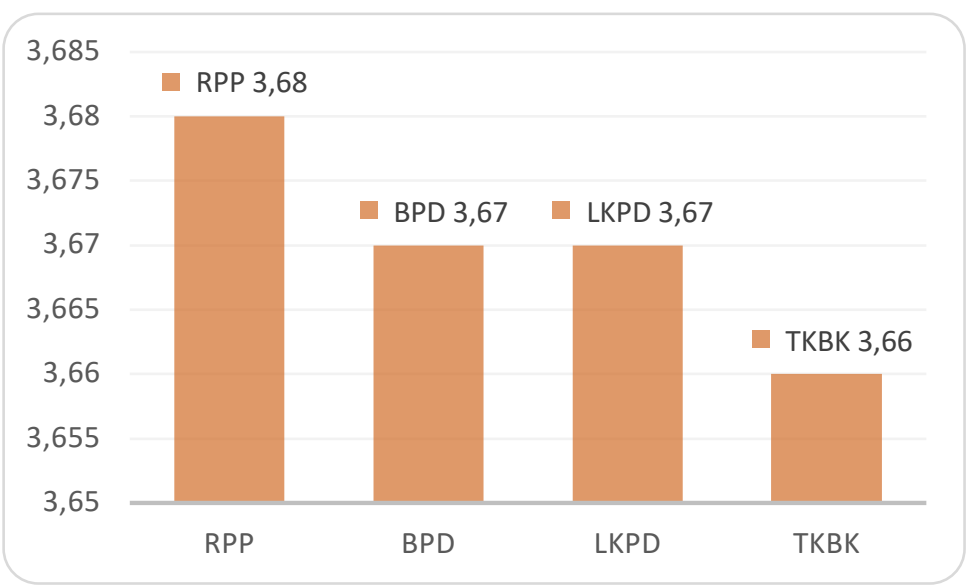

Gambar 1. Diagram Batang Hasil Validasi Ahli tentang Perangkat Pembelajaran Fisika Berbasis Masalah (PBM)

b. Hasil Validasi Ahli untuk Instrumen Penelitian

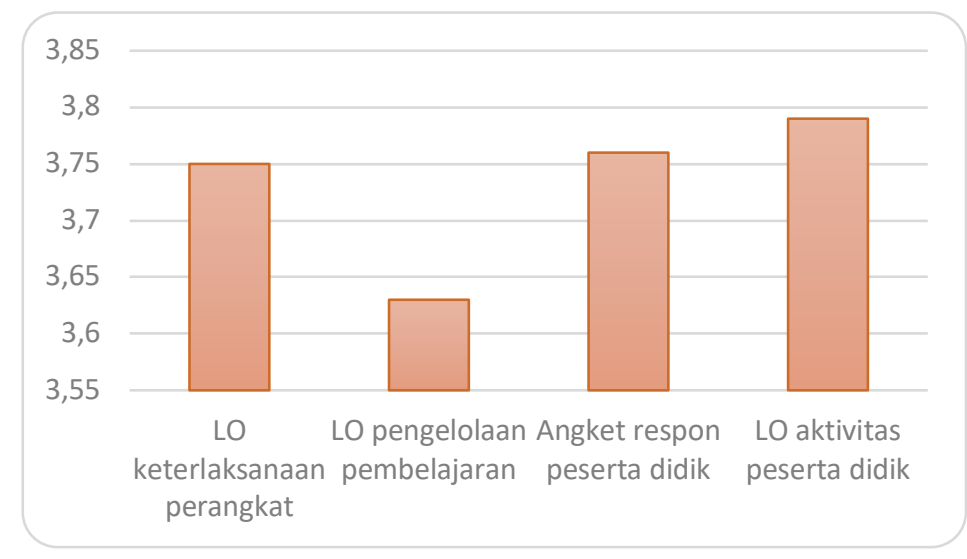

Gambar 2. Diagram Batang Hasil Validasi Instrumen Berbasis Masalah

c. Hasil Pengamatan Keterlaksanaan Perangkat Pembelajaran

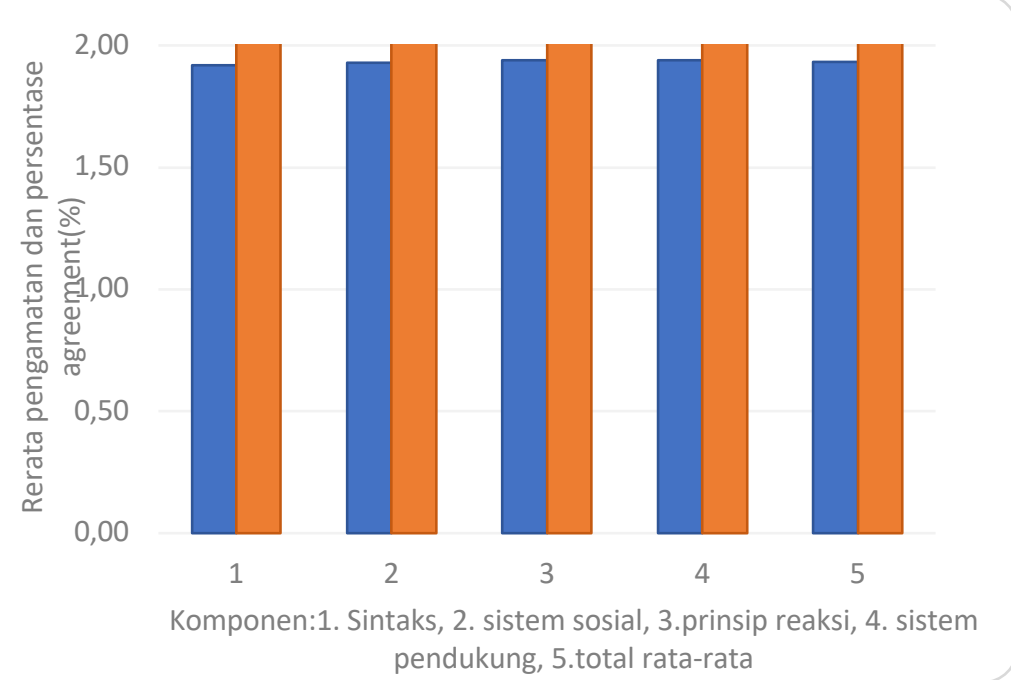

Gambar 3. Diagram Batang Hasil Keterlaksanaan Perangkat Pembelajaran Berbasis Masalah 
d. Hasil Pengamatan Pengelolaan Pembelajaran

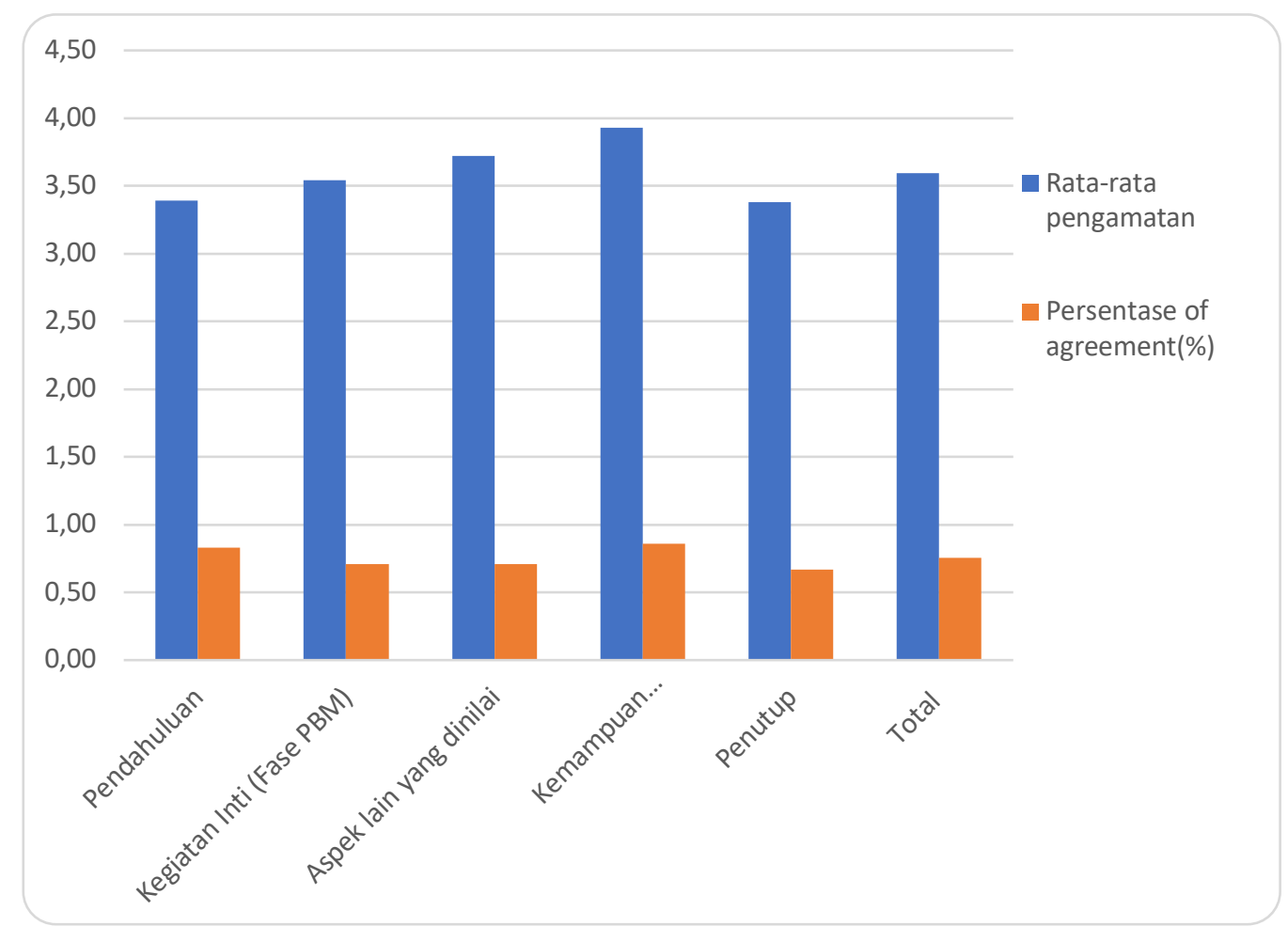

Gambar 4. Diagram Batang Hasil Pengamatan Pengelolaan Pembelajaran Berbasis Masalah

e. Respon Peserta Didik

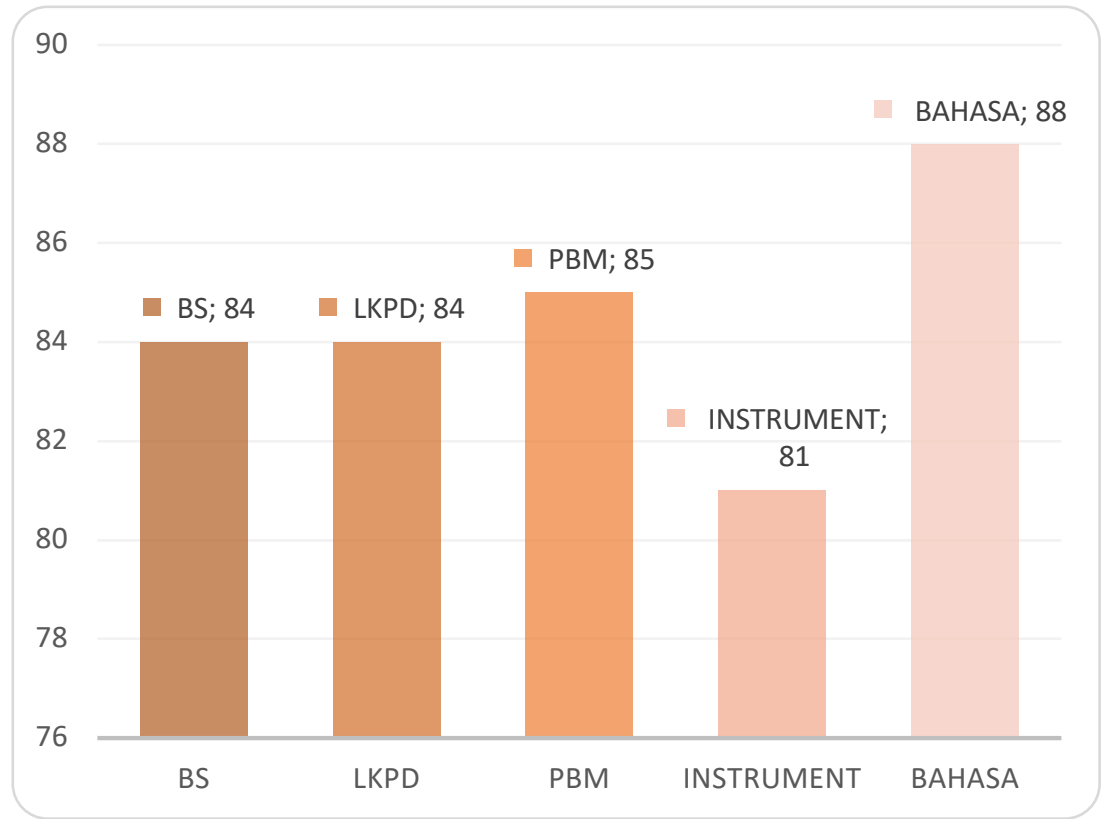

Gambar 5. Diagram Batang Hasil Respon Peserta Didik TerhadapPembelajaran Berbasis Masalah 


\section{Tes Kemampuan Berpikir Kritis}

a. Deskripsi skor tes kemampuan berpikir kritis untuk kelas XI IPA 2 MAN 2 Model Makassar (kelas eksperimen)

Tabel 6. Statistik Deskriptif Skor Tes Kemampuan Berpikir Kritis untuk Kelas Eksperimen pada Materi Fluida Kelas XI IPA 2 MAN 2 Model Makassar

\begin{tabular}{|cc|}
\hline Parameter & Nilai statistik \\
\hline Subjek Penelitian & 35 \\
Skor ideal & 80 \\
Rata-rata & 56,63 \\
\hline Standar Deviasi & 7,17 \\
Rentang Skor & 30 \\
Skor minimum & 39 \\
\hline Skor maksimum & 69 \\
\hline
\end{tabular}

Tabel 7. Distribusi frekuensi skor tes kemampuan berpikir kritis yang diperoleh peserta didik dapat dilihat pada tabel di bawah ini.

\begin{tabular}{|c|c|c|c|}
\hline $\begin{array}{c}\text { Tingkat } \\
\text { kemampuan }\end{array}$ & kategori & $\mathbf{f}$ & $\%$ \\
\hline $65-80$ & Sangat tinggi & 2 & 5,71 \\
\hline $49-64$ & Tinggi & 27 & 77,1 \\
\hline $33-48$ & Sedang & 6 & 17,1 \\
\hline $17-32$ & Rendah & 0 & 0 \\
\hline $0-16$ & $\begin{array}{l}\text { Sangat } \\
\text { rendah }\end{array}$ & 0 & 0 \\
\hline & & 35 & 100 \\
\hline
\end{tabular}

Tabel 7 menunjukkan bahwa dari 35 orang peserta didik yang mengikuti tes kemampuan berpikir kritis, skor rata-rata tes adalah 56,63 dari skor ideal 80 berada dan rentang $49-64$ berada pada kategori 'tinggi'. Dengan demikian, dapat disimpulkan bahwa tingkat kemampuan berpikir kritis peserta didik kelas XI IPA 2 MAN 2 Model Makassar berada pada kategori 'tinggi'.

b. Deskripsi skor tes kemampuan berpikir kritis untuk kelas XI IPA 3 MAN 2 Model Makassar (kelas kontrol) 
Tabel 8. Statistik Deskriptif Skor Tes Kemampuan Berpikir Kritis untuk kelas kontrol pada Materi Fluida pada Kelas XI IPA 3 MAN 2 Model Makassar

\section{Parameter Nilai statistik}

\begin{tabular}{|cc|}
\hline Subjek Penelitian & 35 \\
\hline Skor ideal & 80 \\
\hline Rata-rata & 39,23 \\
\hline Standar Deviasi & 8,32 \\
\hline Rentang Skor & 34 \\
\hline Skor minimum & 24 \\
\hline Skor maksimum & 58 \\
\hline
\end{tabular}

Tabel 9. Distribusi frekuensi skor tes kemampuan berpikir kritis yang diperoleh peserta didik dapat dilihat pada tabel di bawah ini.

\begin{tabular}{|c|c|c|c|}
\hline $\begin{array}{c}\text { Tingkat } \\
\text { kemampuan }\end{array}$ & kategori & f & $\%$ \\
\hline $65-80$ & Sangat tinggi & 0 & 0 \\
\hline $49-64$ & Tinggi & 4 & 11,4 \\
\hline $33-48$ & Sedang & 24 & 68,6 \\
\hline $17-32$ & Rendah & 7 & 20,0 \\
\hline $0-16$ & $\begin{array}{l}\text { Sangat } \\
\text { rendah }\end{array}$ & 0 & 0 \\
\hline & & 35 & 100 \\
\hline
\end{tabular}

Tabel 9 menunjukkan bahwa dari 35 orang peserta didik yang mengikuti tes kemampuan berpikir kritis, skor rata-rata tes adalah 39,23 dari skor ideal 80 berada dan rentang $33-48$ berada pada kategori 'sedang'. Dengan demikian, dapat disimpulkan bahwa tingkat kemampuan berpikir kritis peserta didik kelas XI IPA 3 MAN 2 Model Makassar berada pada kategori 'sedang'.

\section{Hasil pengujian normalitas}

a) Pengujian normalitas data skor tes kemampuan berpikir kritis post test kelas eksperimen

Hasil skor tes kemampuan berpikir kritis posttes pada kelas ekperimen dengan jumlah Sampel 35 diperoleh nilai $\chi^{2}$ hitung $=0,147$. Dengan $\alpha=0,05 \mathrm{dan} \mathrm{dk}=\mathrm{k}-3=3$ dari tabel distribusi chi-kuadrat diperoleh nilai $\chi^{2} 0.95(3)=7,81$. Dengan demikian karena $\chi^{2}$ hitung $<\chi^{2}$ tabel maka dapat disimpulkan bahwa data skor tes kemampuan berpikir kritis (posttes) untuk kelas ekperimen berdistribusi normal.

b) Pengujian normalitas data skor tes kemampuan berpikir kritis (post test) kelas kontrol 
Hasil skor posttes pada kelas kontrol dengan jumlah sampel 35 diperoleh nilai $\chi^{2}$ hitung $=3,90$. Dengan $\alpha=0,05$ dan $\mathrm{dk}=\mathrm{k}-3=3$ dari tabel distribusi chi-kuadrat diperoleh nilai $\chi^{2} 0.95(3)=7,81$. Dengan demikian karena $\chi^{2}$ hitung $<\chi^{2}$ tabel maka dapat disimpulkan bahwa data skor tes kemampuan berpikir kritis (post test) untuk kelas kontrol berdistribusi normal.

\section{Hasil Pengujian Homogenitas}

Hasil skor post test pada kelas ekperimen dan kelas kontrol dengan jumlah sampel kelas ekperiment 35 dan kelas kontrol 35 diperoleh nilai $F_{h i t u n g}=1,34$. Dengan dk pembilang = 35$1=34$ dan $\mathrm{dk}$ penyebut $=35-1=34$, maka pada taraf kesalahan $\alpha=0,05$ diperoleh harga $\mathrm{F}$ tabel $=$ 1,78 (diinterpolasi). Karena $\mathrm{F}$ hitung lebih kecil dari $\mathrm{F}$ tabel $(1,34<1,78)$ maka varians kedua sampel homogen.

\section{Hasil Pengujian Hipótesis}

Berdasarkan hasil analisis data pada kelas ekperimen dan kelas kontrol maka dengan menggunakan statistik t-test (uji-t) jenis Polled Varians diperoleh nilai t hitung =9,35. Kriteria pengujiannya dilakukan uji perbedaan dua rata-rata baik pada kelas eksperimen dan kelas kontrol: uji pihak kanan atau uji-t dengan kriteria pengujian: Tolak Ho jika $t>t_{(1-\alpha)) \text {. Dengan }}$ $\mathrm{dk}=\mathrm{n} 1+\mathrm{n} 2-2=35+35-2=68$ dan $\alpha=0,05$ dari daftar distribusi $\mathrm{t}$ diperoleh nilai $\mathrm{t}_{0,95(68)}=$ 1,669 (di interpolasi).

Karena $t_{\text {hitung }}=9,35>\mathrm{t}_{0,95(68)}=1,669$ berada di dalam daerah penerimaan , maka Ho ditolak atau Ha diterima. Artinya kemampuan berpikir kritis peserta didik yang diajar dengan model pembelajaran berbasis masalah lebih baik dibandingkan dengan peserta didik yang tidak diajar dengan menggunakan model pembelajaran berbasis masalah.

\section{SIMPULAN}

Berdasarkan hasil penelitian yang telah dilakukan pada peserta didik kelas XI IPA 2 MAN 2 Model Makassar, dapat diambil kesimpulan sebagai berikut.

1. Profil perangkat pembelajaran yang dihasilkan dalam penelitian ini meliputi: (1) Rencana Pelaksanaan Pembelajaran, (2) Buku Peserta didik, (3) Lembar Kegiatan Peserta didik dan (4) Tes kemampuan berpikir kritis peserta didik berdasarkan hasil validasi menunjukkan bahwa perangkat pembelajaran berbasis masalah memenuhi kriteria kevalidan, kepraktisan, dan keefektifan.

2. Kemampuan berpikir kritis peserta didik yang diajar dengan model pembelajaran berbasis masalah lebih baik dibandingkan dengan peserta didik yang tidak diajar dengan menggunakan model pembelajaran berbasis masalah

3. Respon peserta didik terhadap perangkat pembelajaran berbasis masalah dan pelaksanaan kegiatan pembelajaran berbasis masalah umumnya memberikan respon positif. 


\section{REFERENSI}

Amri, Sofan. 2010. Proses Pembelajaran Kreatif dan Inovatif dalam Kelas. Jakarta: Prestasi Pustakaraya.

Amir, Taufik. 2009. Inovasi Pendidikan Melalui Problem Based Learning.Jakarta: Kencana

Darwis, Muhammad. 2007. Model Pembelajaran Matematika yang Melibatkan Kecerdasan Emosional. Disertasi Program Pascasarjana Program Studi Pendidikan Matematika. Surabaya: Universitas Negeri Surabaya.

Depdiknas. 2006. Kurikulum Tingkat Satuan Pendidikan. Jakarta: Depdiknas.

Djaali dan Pudji. 2008. Pengukuran dalam Bidang Pendidikan. Jakarta: PT Grasindo.

Fisher,Alec.2009. Berpikir Kritis. Jakarta: Erlangga.

Hadi, Sutrisno.1991. Analisis Butir untuk Instrumen. Yogyakarta: Andi Offset.

Hajrah, Sitti. 2009. Pengembangan Perangkat Pembelajaran Matematika Berbasis Masalah untuk Meningkatkan Kreativitas Peserta didik. Tesis. Tidak diterbitkan. Makassar: Program Pascasarjana Universitas Negeri Makassar.

Nurdin. 2007. Model Pembelajaran Matematika yang Menumbuhkan Kemampuan Metakognitif untuk Menguasai Bahan Ajar. Disertasi. tidak diterbitkan. Surabaya: PPs UNESA.

Sahabuddin.2007.Mengajar dan Belajar.Makassar.Badan Penerbit Universitas Negeri Makassar.

Said.2009. Pengembangan Model Perangkat Pembelajaran Fisika Melalui Pendekatan Discovery Untuk Meningkatkan Kemampuan Proses Sains. Tesis. Tidak diterbitkan. Makassar: Program Pascasarjana Universitas Negeri Makassar.

Sagala, Syaiful. 2010. Konsep dan Makna Pembelajaran. Bandung: Alfabeta.

Slameto. 2003. Belajar dan Faktor-Faktor yang Mempengaruhinya. Jakarta: Rineka Cipta.

Sudjana, 2005. Metoda Statistika. Bandung: Tarsito

Sugiono, 2010. Statistika untuk Penelitian. Bandung: Alfabeta

Riyanto, Yatim. 2010. Paradigma Baru Pembelajaran: Sebagai Referensi bagi Guru/Pendidik dalam Implementasi Pembelajaran yang Efektif dan Berkualias. Jakarta: Kencana.

Riduwan. 2008. Metode dan Teknik Menyusun Tesis. Bandung : Alfabeta.

Rusman. 2010. Model-Model pembelajaran. Jakarta: Grafindo

Sugiarti, Henik. 2005. Meningkatkan Kemampuan Berpikir Kritis Dan Hasil Belajar Peserta didik SMPN I Tambakromo Kabupaten Pati Melalui Pembelajaran Matematika Berbasis Masalah. Semarang.Universitas Negeri Semarang.

Trianto. 2010. Model Pembelajaran Terpadu. Jakarta: Bumi Aksara.

Trianto.2010. Mendesain Model Pembelajaran Inovatif-Progresif. Jakarta: Kencana

Zamroni \& Mahfudz.2009. Panduan Teknis Pembelajaran yang Mengembangkan

Critical Thinking. jakarta: kencana 